\title{
PENINGKATAN KEMAMPUAN MENULIS TEKS DESKRIPTIF BERBAHASA INGGRIS MELALUI TEKNIK CLUSTERING PADA PROGRAM STUDI TADRIS BAHASA INGGRIS DI STAIN GAJAH PUTIH TAKENGON
}

\author{
Delfia Herwanis ${ }^{1}$, Susidamaiyanti ${ }^{2}$ \\ ${ }^{1,2}$ IAIN Takengon, Aceh Tengah, Aceh \\ Email: delfiaherwanis3@gmail.com ${ }^{1}$, susidamaiyanti85@gmail.com²
}

\begin{abstract}
Descriptive Text is one of the materials taught in the Writing II course for students in the Second Semester of English Department (Tadris Bahasa Inggris/ TBI). This study aimed to improve the TBI students' writing ability in English of the second semester in a descriptive text through the Clustering Technique. This study's subjects were all the second semester of TBI students in the academic year 2018/2019; they were 11 students. This research was a Classroom Action Research (CAR). The base data were obtained from the evaluation results of the students' descriptive text ability. The results of this study indicated that there was an improvement in students' descriptive text-ability through the clustering technique of the second semester of TBI students in the academic year 2018/2019 at STAIN Gajah Putih Takengon.
\end{abstract}

Keywords: Descriptive Text, Writing, Clustering Technique, Student

\begin{abstract}
Abstrak: Teks Deskriptif merupakan salah satu materi yang diajarkan pada Mata kuliah Writing II bagi mahasiswa Program Studi Tadris Bahasa Inggris Semester II. Tujuan penelitian ini adalah untuk meningkatkan kemampuan menulis teks deskriptif dalam Bahasa Inggris bagi mahasiswa Prodi TBI melalui Clustering Technique. Subjek penelitian ini adalah seluruh mahasiswa Prodi TBI Semester II TA 2018/2019 berjumlah 11 orang. Penelitian ini adalah penelitian tindakan kelas (PTK). Data awal diperoleh dari hasil evaluasi kemampuan menulis teks deskriptif. Hasil penelitian ini menunjukkan bahwa adanya peningkatan kemampuan menulis teks desriptif melalui clustering technique mahasiswa Prodi TBI Semester II TA 2018/2019 di STAIN Gajah Putih Takengon.
\end{abstract}

Kata Kunci: Teks Deskriptif, Menulis, Teknik clustering, Mahasiswa

\section{PENDAHULUAN}

Writing merupakan salah satu mata kuliah wajib pada Program Studi Tadris Bahasa Inggris. Mata Kuliah ini ditawarkan berjenjang dalam 4 level yaitu Writing I, Writing II, Writing III dan Writing IV. Penomoran mata kuliah ini dimaksudkan bahwa mata kuliah ini merupakan mata kuliah prasyarat, di mana setiap mahasiswa dibenarkan mengambil mata kuliah Writing II jika telah lulus Writing I, begitu seterusnya.

Pada penelitian ini penulis memilih teks deskriptif sebagai materi, dikarenakan teks ini merupakan teks yang paling sering digunakan dalam penulisan karya ilmiah untuk menggambarkan secara detail data-data yang diperoleh dalam penelitian. Adalah suatu kerugian bagi seorang mahasiswa jika tidak mahir dalam menulis teks deskripsi, karena mereka akan menghadapi kesulitan dalam menyusun tugas akhir nantinya. Sebagaimana yang dikatakan oleh Wyrick (1987) penulis deskripsi menciptakan kata-kata melalui 
penggambaran orang, tempat dan benda dengan menggunakan pemilihan detail yang cermat sehingga membuat pembaca terkesan. Ini menjelaskan bahwa teks deskripsi ini merupakan salah satu teks yang sangat cocok digunakan untuk menjelaskan gambaran tentang suatu objek apapun secara rinci dan detail.

Untuk mengajarkan teks deskriptif berbahasa Inggris, ada beberapa teknik pengumpulan informasi yang dapat digunakan oleh penulis pemula dalam merangkai ideide, salah satunya adalah teknik clustering. Pemilihan teknik clustering didasarkan pada hasil survey terhadap mahasiswa yang berisi "teknik pengumpulan informasi menulis teks deskriptif berbahasa Inggris yang paling diminati oleh mahasiswa Semester II Program Studi Tadris Bahasa Inggris TA 2018/2019”. Hasil survey menunjukkan bahwa 8 orang mahasiswa menyukai teknik clustering, 2 orang menyukai brainstorming, 1 orang menyukai free writing. Inilah salah satu alasan peneliti memilih teknik clustering dalam mengajarkan teks deskriptif berbahasa Inggris. Sehingga rumusan masalah penelitian ini adalah "Apakah teknik clustering mampu meningkatkan kemampuan menulis teks deskriptif berbahasa Inggris bagi mahasiswa Semester II Prodi Tadris Bahasa Inggris TA 2018/2019 di STAIN Gajah Putih Takengon?”.

\section{LANDASAN TEORI}

\section{Keahlian Menulis/ Kemampuan Menulis}

Keahlian menulis (writing) adalah cara seseorang mengeluarkan ide, pengalaman dan pikirannya melalui sebuah tulisan (Finocchiaro, 1974). Aktifitas menulis merupakan suatu bentuk manifestasi kemampuan dan keterampilan berbahasa yang paling akhir dikuasai oleh pembelajar bahasa setelah kemampuan mendengar, berbicara dan membaca. (Iskandarwassid, 2011). Sedangkan Dumais (1988) menjelaskan bahwa menulis dengan menggunakan bahasa Inggris merupakan kegiatan dalam mengekspresikan ide, perasaan, pendapat, dan lain-lain dalam bahasa Indonesia dan kemampuan mengekspresikan hal yang sama secara tertulis dalam bahasa Inggris. Jadi menulis juga merupakan kemampuan dalam memadukan ide, pengalaman dan perasaan dalam bentuk tulisan baik dalam bahasa Indonesia maupun dalam bahasa Inggris. Lebih lanjut Nunan (2003) menggambarkan menulis sebagai a) tindakan fisik dan mental; b) tindakan untuk mengekspresikan dan mengesankan, dan c) sebuah proses dan produk.

Menulis dalam penelitian ini dimaknai sebagai kemampuan menuangkan ide menggunakan teknik clustering yang melibatkan tindakan fisik dan mental melalui suatu 
proses, sehingga setiap mahasiswa dapat menghasilkan teks deskriptif berbahasa Inggris sesuai dengan struktur umum (generic structure) dan fitur bahasa (language features) yang harus diikuti dalam penulisan teks deskriptif.

\section{Tahapan Dalam Menulis}

Banyak ahli yang menulis tentang tahapan menulis dalam bahasa Inggris. Secara umum dapat disimpulkan tahapan-tahapan dalam proses menulis dibagi kepada 4 bagian yaitu: 1) prewriting, 2) drafting, 3) revising, dan 4) editing (Albright, Zoe L and Langan, 2013; Geyte, 2013; Murray, 2012; Gordon, 2009; Nor \& Ibrahim, 2009; Murray, Rowena and Moore, 2006; Oshima, Alice and Hogue, 2006; Bailey, 2003; Bryne, 1988; Cleant, Brooks and Penn, n.d).

Dari rincian tahapan-tahapan proses menulis di atas dapat dipahami bahwa untuk menghasilkan sebuah tulisan yang baik, maka seorang penulis harus melalui proses yang panjang. Dalam arti tidak ada tulisan bagus dihasilkan dalam proses cepat dan singkat. Seorang penulis harus merancang tulisan sedemikian rupa mulai dari penentuan topik dan cara mengembangkan topik yang akan ditulis.

Senada dengan penjelasan di atas Collerson (n.d.) menjelaskan bahwa menulis sebagai proses yang ditandai dengan adanya latihan menulis secara repetisi atau berulangulang, repetisi ini disebut dengan rehearsal. Proses pembelajaran menulis dengan model ini dilaksanakan dalam beberapa fase yang berbeda. Pada fase-fase tersebut, peserta didik diberikan kesempatan untuk merevisi, memperbaiki, dan melakukan proofreading pada tulisan yang dihasilkan.

\section{Teks Deskriptif}

Teks deskriptif merupakan salah satu jenis teks yang dipelajari pada semester II Prodi TBI. Perbedaan teks dalam bahasa Inggris dapat dilihat dari struktur umum (generic structure) dan fitur bahasa (language features) yang ada pada setiap teks, dan karena adanya perbedaan inilah kemudian teks-teks dalam bahasa Inggris dibagi pada beberapa macam teks, diantaranya: teks narrative, recount, procedure, deskriptive, report, explanation, hortatory exposition, spoof, review, anecdote, new item, advertisement, announcement.

Pengertian Teks deskriptif secara umum adalah penggambaran tentang orang, tempat dan benda (Littlejohn, 2005; Ruby and Diamond, 2001; Gerot, L., \& Wignell, 1995; Pardiyono, 2007). Teks deskriptif ini melibatkan panca indera (sensory) dalam tujuan penulisannya, maksudnya sebuah teks deskriptif itu dikatakan berhasil, jika 
pembaca seolah-olah melihat langsung benda yang digambarkan oleh penulis. Sebagaiamana Nor \& Ibrahim (2009) menjelaskan dengan membandingkan hal-hal yang cukup familiar dengan budaya dan gaya hidup pembaca, sebagai contoh jika pembaca belum pernah melihat, mencicipi, atau mencium aroma buah durian, penulis tidak akan dapat mengemukan ide-idenya tanpa menggunakan perbandingan dengan benda lainnya. Blanchard and Cristine (1994) dengan pernyataan lain menyampaikan bahwa bagian terpenting pada penulisan teks deskriptif adalah kejelasan dan keefektifan penulis dalam menggambarkan suatu objek menjadi persis seperti objek digambarkan.

Struktur umum (generic structure) teks deskriptif adalah identifikasi (identification) dan deskripsi (description). Identification berisi identifikasi tentang hal apa yang akan dideskripsikan. Description menggambarkan tentang hal yang telah diidentifikasi. Jadi struktur umum teks deskripsi ini sangat sederhana hanya terdiri dari 2 (dua) item, namun dalam tahapan penulisan teks deskriptif hendaknya mengikuti language features (fitur bahasa) yaitu: menggambarkan sesuatu secara detail, menyertakan ciri-ciri dari yang digambarkan, menggunakan kata sifat, menggunakan simple present tense dan menggunakan action verb (Gerot \& Wignell, 1995).

\section{Teknik Clustering}

Hampir semua buku tentang Writing membahas tentang proses menulis (Writing Process), dan dalam writing process dikenal dengan adanya invention techniques. Salah satu invention techniques yang digunakan dalam mengumpulkan informasi disebut dengan clustering. Menurut Oshima \& Hogue (2006: 269) Clustering merupakan aktifitas brainstorming lain yang dapat digunakan untuk menghasilkan ide. Sebagai tambahan Nor \& Ibrahim (2009) menjelaskan dalam implementasinya istilah mapping dan diagramming sama maknanya dengan clustering. Ini merupakan salah satu cara yang bagus untuk memulai sebuah tulisan bagi pemula, agar ide-ide yang muncul dalam pikiran penulis tidak hilang.

Penerapan teknik clustering ini dapat dimulai dari menentukan topik yang akan dibahas, kemudian gunakan kotak-kotak, garis-garis, atau lingkaran-lingkaran pada ideide yang muncul. Ide-ide yang muncul dapat dituliskan dalam bentuk kata (word) atau kata majemuk (phrase). Berikut ini contoh teknik clustering secara sederhana: 


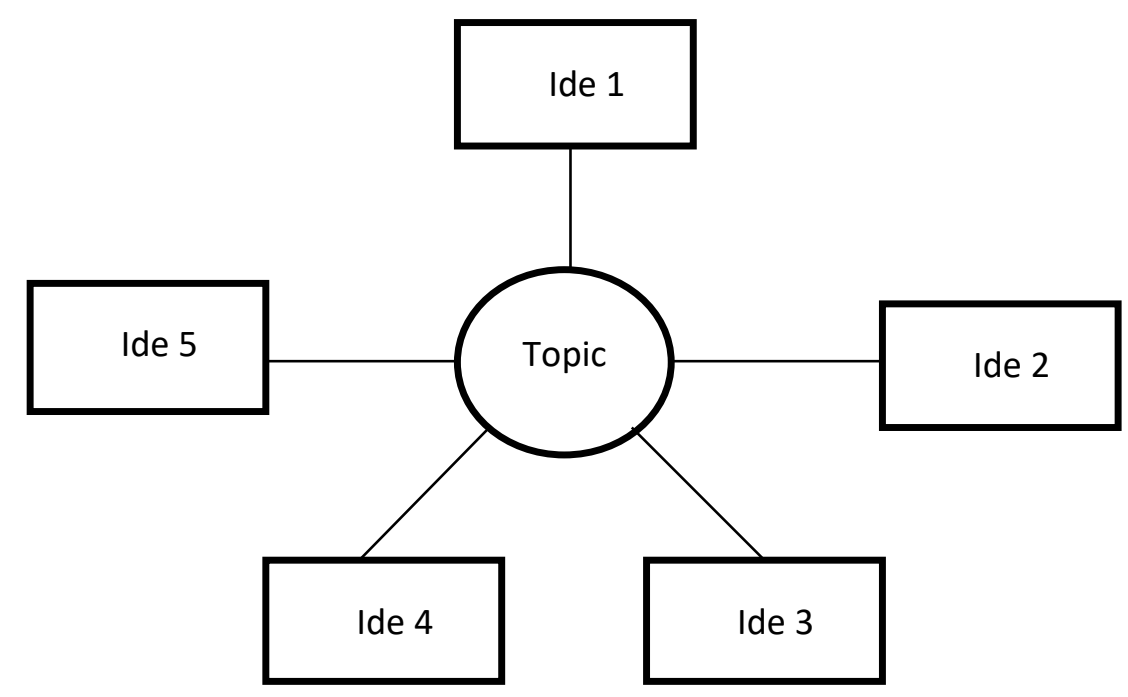

Figure 1. Bentuk dasar teknik clustering

\section{METODE PENELITIAN}

\section{Desain Penelitian}

Penelitian ini adalah penelitian tindakan kelas, terdiri dari 2 siklus, dengan mengadobsi Kemis dan McTaggart dalam Nunan (1995) menyatakan penelitian tindakan adalah penelitian deskriptif yang dilakukan oleh tenaga pengajar di kelasnya sendiri, tanpa melibatkan orang lain, yang bertujuan untuk meningkatkan pemahaman kita, daripada mengubah fenomena yang sedang diselidiki. Sejalan dengan itu beberapa ahli menyatakan bahwa penelitian tindakan merupakan penelitian yang membawa kesenjangan antara penelitian dan tindakan dengan memadukan antara teori dan pelaksanaan (Clark, J., Thorpe, R., Anderson, L., and Gold, 2006; Brinberg, D., \& Hirschman, 1986). Subjek penelitian dalam penelitian ini adalah seluruh mahasiswa Semester II Prodi TBI TA 2018/2019 di STAIN Gajah Putih Takengon, berjumlah 11 orang. Penelitian ini dilakukan pada Semester Genap TA 2018/2019 (bulan April, Juni dan Juli 2019).

Tahapan-tahapan penelitian tindakan kelas dalam penelitian ini mencakup 4 (empat) tahapan:

\section{1) Perencanaan}

Pada tahapan ini peneliti membuat perencanaan pembelajaran yang matang setelah peneliti mengetahui permasalahan yang dihadapi mahasiswa dalam pembelajaran 
writing, khususnya materi deskriptif. Tahapan ini juga merupakan rancangan solusi terhadap permasalahan yang ditemui di lapangan.

2) Tindakan

Tahapan ini merupakan tahapan pengaplikasian rancangan yang telah dirumuskan sedemikian rupa pada tahapan perencanaan. Tindakan pembelajaran dengan menggunakan teknik clustering untuk meningkatkan kemampuan menulis teks deskriptif berbahasa Inggris.

3) Observasi

Observasi dilakukan bersamaan dengan proses penerapan teknik clustering dalam pembelajaran.

4) Refleksi

Tahapan refleksi merupakan tahapan penarikan kesimpulan terhadap proses pembelajaran yang dilakukan. Pada tahapan inilah peneliti menentukan apakah pembelajaran sudah memenuhi standar atau akan lanjut ke siklus berikutnya. Jika kesimpulan menunjukkan bahwa pembelajaran belum tuntas, maka peneliti akan menambah siklus berikutnya dengan mengikuti tahapan yang sama yaitu dimulai dari perencanaan, tindakan, observasi dan refleksi.

\section{Instrumen Penelitian}

Instrumen yang digunakan dalam penelitian adalah:

a) Lembaran observasi

Observasi dapat membantu peneliti dalam mendokumentasikan proses pembelajaran yang dilakukan, di mana lembar observasi yang telah dirancang oleh peneliti dengan beberapa list yang diamati dapat memonitor kegiatan yang dilakukan secara sistematis.

b) Test

Test diberikan pada pertemuan pertama sebagai data awal kemampuan menulis teks deskripsi mahasiswa semester II Prodi TBI STAIN Gajah Putih Takengon. Dan proses ini peneliti namai dengan Pre-cycle Test. Pada akhir pertemuan setelah peneliti melakukan tahapan-tahapan dalam penelitian tindakan kelas sebagaimana yang telah dijabarkan di atas, peneliti memberikan test akhir yang disebut dengan Post-cycle-test.

Penilaian teks deskriptif, peneliti menggunakan rubrik penilaian Brown (2007) sebagaimana tergambar pada table di bawah ini: 
Table 1. Rubrik penilaian teks deskriptif

\begin{tabular}{|c|c|c|}
\hline Aspek & $\begin{array}{l}\text { Rentang } \\
\text { Nilai }\end{array}$ & Deskripsi \\
\hline \multirow[t]{4}{*}{$\begin{array}{l}\text { Organisasi } \\
\text { Identifikasi } \\
\text { Deskripsi }\end{array}$} & $86-100$ & $\begin{array}{l}\text { Identifikasi lengkap dan uraian } \\
\text { disusun dengan menggunakan kata } \\
\text { penghubung yang tepat. }\end{array}$ \\
\hline & $71-85$ & $\begin{array}{l}\text { Identifikasi hampir lengkap dan } \\
\text { uraian disusun dengan menggunakan } \\
\text { kata penghubung yang hampir tepat. }\end{array}$ \\
\hline & $50-70$ & $\begin{array}{l}\text { Identifikasi tidak lengkap dan uraian } \\
\text { disusun tidak menggunakan kata } \\
\text { penghubung yang tepat. }\end{array}$ \\
\hline & $0-49$ & $\begin{array}{l}\text { Sangat sukar menemukan } \\
\text { identifikasi dan tidak menggunakan } \\
\text { kata penghubung. }\end{array}$ \\
\hline \multirow{5}{*}{$\begin{array}{l}\text { Vocabulary } \\
\text { (Kosakata) }\end{array}$} & $86-100$ & Pilihan kata dan bentuk kata efektif. \\
\hline & $71-85$ & $\begin{array}{l}\text { Beberapa penyalahgunaan kosakata } \\
\text { dan bentuk kata tetapi tidak } \\
\text { mengubah arti. }\end{array}$ \\
\hline & $50-70$ & Penggunaan kosakata dan bentuk \\
\hline & $0-49$ & $\begin{array}{l}\text { kata yang terbatas dan } \\
\text { membingungkan. }\end{array}$ \\
\hline & & $\begin{array}{l}\text { Pengetahuan yang sangat buruk } \\
\text { tentang kosakata dan bentuk kata } \\
\text { sehingga tidak dapat dimengerti. }\end{array}$ \\
\hline \multirow[t]{5}{*}{ Grammar } & $86-100$ & $\begin{array}{l}\text { Sangat sedikit kesalahan tata bahasa } \\
\text { (grammar) atau ketidak akuratan } \\
\text { dalam menyusun kalimat. }\end{array}$ \\
\hline & $71-85$ & Terdapat beberapa ketidaksesuaian \\
\hline & & $\begin{array}{l}\text { tata bahasa tetapi tidak } \\
\text { mempengaruhi makna. }\end{array}$ \\
\hline & $50-70$ & Banyak ketidaktepatan tata bahasa. \\
\hline & $0-49$ & $\begin{array}{l}\text { Sering terjadi ketidaktepatan tata } \\
\text { bahasa. }\end{array}$ \\
\hline
\end{tabular}

\section{Teknik Analisa Data}

Untuk mendapatkan mean mahasiswa, peneliti merujuk pada Sudijono (2008) sebagai berikut:

$M x=\frac{\sum X}{N}$

Keterangan:

$\mathrm{Mx} \quad$ : Mean

$\mathrm{X}$ : Nilai Mahasiswa

$\mathrm{N} \quad$ : Jumlah Mahasiswa 
Selanjutkan untuk menentukan kriteria ketuntasan minimum (KKM) menggunakan rumus:

$P=\frac{F}{N} \times 100 \%$

Keterangan:

$\mathrm{P}$ : Persentase

F : Jumlah persentase keseluruhan

$\mathrm{N}$ : Jumlah mahasiswa

Penelitian ini juga menghasilkan data kualitatif, maka untuk menganalisa data kulitatif peneliti menggunakan tahapan analisa data sebagai berikut: a) reduksi data, b) menyajikan data, c) menarik kesimpulan, d) verifikasi.

\section{HASIL DAN PEMBAHASAN}

\section{Hasil Penelitian}

\section{Paparan Kegiatan Siklus 1}

Beberapa hal yang dilakukan oleh penulis sebelum merancang rencana tindakan dalam pembelajaran menulis deskriptif teks berbahasa Inggris dengan menggunakan teknik clustering bagi mahasiswa semester II di STAIN Gajah Putih Takengon adalah melakukan identifikasi awal tentang pengalaman dan kesulitan mahasiswa dalam membuat tulisan berbahasa Inggris, serta membagi survey kepada mahasiswa untuk mengidentifikasi teknik yang diminati oleh mahasiswa dalam pembelajaran menulis berbahasa Inggris.

Setelah identifikasi dilakukan, peneliti melanjutkan dengan merancang dan menyusun beberapa perangkat yang diperlukan dalam pembelajaran menulis teks deskriptif dalam bahasa Inggris dengan menggunakan teknik clustering sebagai berikut: rencana pembelajaran, sumber belajar, bahan yang akan diajarkan, waktu, media pembelajaran, dan form penilaian.

Pelaksanaan kegiatan pembelajaran pada siklus 1 dirancang sebagai berikut:

1) Penulis bertindak sebagai pengajar dan pengamat pelaksanaan pembelajaran menulis teks deskriptif berbahasa Inggris menggunakan teknik clustering sesuai dengan rencana pembelajaran yang telah disusun.

2) Kegiatan pembelajaran direncanakan diawali dengan persepsi, kemudian mahasiswa diminta memilih topik yang disukai untuk ditulis dengan menggunakan teknik 
clustering dan mendampingi mahasiswa dalam mempraktekkan teknik clustering untuk mengumpulkan informasi yang ada dalam pikiran mereka agar tidak hilang.

3) Menginstruksikan mahasiswa untuk mengembangkan ide yang telah digambarkan melalui teknik clustering tadi menjadi kalimat sempurna dan mengembangkannya dalam bentuk paragraph.

4) Memastikan paragraph yang ditulis mahasiswa sesuai dengan generic structure dan language features pada deskriptif teks berbahasa Inggris, menilai hasil tulisan mereka berdasarkan rubrik penilaian yang telah disajikan pada tabel rubrik penilaian di atas.

Hasil penelitian ini terdiri dari data kuantitatif diperoleh dari hasil tes, dan data kualitatif diperoleh dari data observasi.

1. Hasil Tes

a) Hasil Tes Menulis Teks Deskripsi Mahasiswa Semester II Prodi TBI Siklus I (precycle-test)

Tabel 2. Hasil tes siklus 1

\begin{tabular}{|c|c|c|c|c|c|c|c|}
\hline \multirow[t]{2}{*}{ No } & \multirow{2}{*}{$\begin{array}{c}\text { Nama } \\
\text { (Inisial) }\end{array}$} & \multirow[t]{2}{*}{$\mathbf{L} / \mathbf{P}$} & \multicolumn{3}{|c|}{ Skor } & \multirow[t]{2}{*}{ Jumlah } & \multirow[t]{2}{*}{ Rata-Rata } \\
\hline & & & Organization & Vocab & Grammar & & \\
\hline 1 & DS & $\mathrm{P}$ & 55 & 60 & 55 & 170 & 56,7 \\
\hline 2 & DA & $\mathrm{P}$ & 70 & 65 & 65 & 200 & 66,7 \\
\hline 3 & EM & $\mathrm{P}$ & 75 & 70 & 75 & 220 & 73,3 \\
\hline 4 & LL & $\mathrm{P}$ & 45 & 50 & 40 & 135 & 45 \\
\hline 5 & LD & $\mathrm{P}$ & 60 & 55 & 60 & 175 & 58,3 \\
\hline 6 & RW & $\mathrm{L}$ & 65 & 60 & 55 & 180 & 60 \\
\hline 7 & SW & $\mathrm{P}$ & 70 & 70 & 75 & 215 & 71,7 \\
\hline 8 & SWR & $\mathrm{P}$ & 65 & 60 & 60 & 185 & 61,7 \\
\hline 9 & $\mathrm{SL}$ & $\mathrm{P}$ & 70 & 70 & 70 & 210 & 70 \\
\hline 10 & TQ & $\mathrm{L}$ & 75 & 70 & 65 & 210 & 70 \\
\hline 11 & WTM & $\mathrm{L}$ & 60 & 55 & 50 & 165 & 55 \\
\hline & Total & & 710 & 685 & 670 & 2065 & 688,4 \\
\hline & Rata-Rata & & 64,5 & 62,3 & 60,1 & 187,7 & 62,6 \\
\hline
\end{tabular}

\section{Paparan Kegiatan Siklus 2}

Kegiatan pembelajaran siklus 2 ini merupakan kegiatan lanjutan yang bertujuan untuk memperbaiki proses pembelajaran pada siklus 1. Berdasarkan hasil refleksi pada siklus 1, penulis menemukan bagian-bagian yang harus diperbaiki dalam pembelajaran pada siklus 2. Hal yang harus diperbaiki adalah suasana pembelajaran, yang mana pada siklus 1, mahasiswa langsung diminta untuk mempraktekkan teknik clustering dalam menulis teks deskriptif, ternyata kegiatan ini belum maksimal meningkatkan kemampuan 
menulis teks desktiptif berbahasa Inggris mereka, maka penulis mensiasati dengan memperbaiki proses pembelajaran yaitu dengan cara:

- Memberi kesempatan kepada setiap mahasiswa untuk menyajikan ide yang telah disusunnya melalui teknik clustering ke depan kelas masing-masing 5 menit.

- Mahasiswa lain memberikan pendapat terkait topik yang dibahas untuk dimasukkan ke dalam clustering yang disajikan di papan tulis.

- Setelah selesai proses penyusunan informasi melalui teknik clustering di atas, kemudian proses selanjutnya sama dengan proses pada siklus 1 yaitu:

- Menginstruksikan mahasiswa untuk mengembangkan ide yang telah digambarkan melalui teknik clustering tadi menjadi kalimat sempurna dan mengembangkannya ke dalam bentuk paragraph.

- Memastikan paragraph yang ditulis mahasiswa sesuai dengan generic structure dan language features pada deskriptif teks berbahasa Inggris.

Kegiatan pembelajaran dilakukan dalam 2 x pertemuan yaitu 2 x 90 menit.

b) Hasil Tes Menulis Teks Deskripsi Siklus 2 (postcycle-test)

Tabel 3. Hasil tes siklus 2

\begin{tabular}{llrrrrrr}
\hline No & $\begin{array}{l}\text { Nama } \\
\text { (Inisial) }\end{array}$ & L/P & \multicolumn{3}{c}{ Skor } & \multicolumn{3}{c}{ Jumlah } & $\begin{array}{l}\text { Rata- } \\
\text { Rata }\end{array}$ \\
& & & Organization & Vocab & Grammar & \\
\hline 1 & DS & P & 70 & 70 & 65 & 205 & 68,3 \\
2 & DA & P & 85 & 80 & 85 & 250 & 83,3 \\
3 & EM & P & 90 & 85 & 85 & 260 & 86,7 \\
4 & LL & P & 55 & 60 & 50 & 165 & 55 \\
5 & LD & P & 80 & 70 & 75 & 225 & 75 \\
6 & RW & L & 75 & 80 & 75 & 230 & 76,7 \\
7 & SW & P & 86 & 86 & 88 & 260 & 86,7 \\
8 & SWR & P & 80 & 86 & 80 & 246 & 82 \\
9 & SL & P & 88 & 85 & 86 & 259 & 86,3 \\
10 & TQ & L & 90 & 86 & 86 & 262 & 87,3 \\
11 & WTM & L & 75 & 70 & 65 & 210 & 70 \\
& Total & & 874 & 88 & 840 & 252 & 853 \\
& Rata-Rata & & 79,4 & 78 & 76,4 & 233,8 & 77,9 \\
\hline
\end{tabular}

Dari hasil tes pada siklus 1 dan siklus 2 dapat ditarik kesimpulan bahwa: pada siklus 1 kemampuan menulis teks deskripsi mahasiswa hanya 4 (empat) orang yang memenuhi kriteria ketuntasan minimal (KKM), dan pada siklus 2 bertambah 5 orang mahasiswa yang memenuhi KKM, sehingga jumlah seluruh mahasiswa yang memenuhi KKM menjadi $9(81 \%)$ orang dan $2(19 \%)$ orang tidak memenuhi KKM. Ini 
menunjukkan bahwa pembelajaran teks deskriptif dengan menggunakan teknik clustering mampu meningkatkan kemampuan menulis teks deskripsi mahasiswa semester II Prodi TBI pada STAIN Gajah Putih Takengon.

2. Hasil Observasi

a) Hasil Observasi Siklus 1

Observasi dilakukan pada saat proses pembelajaran meliputi 3 (tiga) indikator yaitu: perhatian mahasiswa saat proses pembelajaran berlangsung, kesiapan mahasiswa dalam menerima instruksi-instruksi saat proses pembelajaran, antusias mahasiswa dalam praktek menulis. Adapun observasi berbentuk check list. Hasil observasi pada siklus pertama ini menunjukkan bahwa sebanyak $5(45 \%)$ orang mahasiswa aktif mengikuti proses pembelajaran dan tampak antusias, namun 6 (55\%) orang mahasiswa kurang aktif, bahkan tidak aktif dalam mengikuti proses pembelajaran.

b) Hasil Observasi Siklus 2

Pada siklus kedua ini hasil observasi menunjukkan bahwa 9 (81\%) mahasiswa aktif dan antusias mengikuti proses pembelajaran, dan ini berbanding lurus dengan hasil tes yang diraih oleh mahasiswa pada siklus 1, hanya 2 (19\%) mahasiswa kurang aktif dan kurang antusias dalam mengikuti proses pembelajaran. Hasil observasi ini menunjukkan bahwa teknik clustering mampu meningkatkan keaktifan dan antusiasme mahasiswa dalam membuat tulisan deskriptif.

\section{Pembahasan}

\section{Analisis Temuan Siklus 1}

\section{Tindakan}

Pembelajaran diawali dengan kegiatan pendahuluan yang dilakukan oleh pengajar. Dosen membuka pembelajaran dengan apersepsi dan membangkitkan motivasi belajar mahasiswa. Kemudian dosen mengemukakan tema materi pelajaran dan tujuan pembelajaran. Mahasiswa tampak kurang relax dan masih bingung mengikuti instruksi yang disampaikan. Pembelajaran dilaksanakan sesuai dengan perencanaan pembelajaran pada siklus 1 dan berlangsung selama 2 x pertemuan. Pada pertemuan pertama terlihat mahasiswa kurang semangat dalam pembelajaran, dari 11 orang mahasiswa 5 orang mengikuti proses pembelajaran dengan antusias dan 6 orang lainnya kurang antusias. 


\section{Observasi/ Pengamatan}

Hal- hal yang terjadi dalam proses pembelajaran menulis teks deskriptif berbahasa Inggris dengan menggunakan teknik clustering pada semester II Prodi TBI pada siklus 1 adalah:

1) Suasana pembelajaran kurang relax

2) Mayoritas mahasiswa bingung menulis ide dari topik yang telah dipilihnya sendiri.

3) Mayoritas mahasiswa hanya mampu mengembangkan idenya menjadi 3 bagian kelas saja.

Refleksi

Dari hasil pengamatan yang telah dilakukan tersebut dapat disimpulkan bahwa kegiatan pembelajaran pada siklus 1 belum optimal, karena mayoritas mahasiswa belum mampu mengembangkan idenya lebih banyak dan proses pembelajaran kurang menyenangkan. Maka berdasarkan kesimpulan ini disusunlah rencana pembelajaran menulis teks deskriptif dalam berbahasa Inggris menggunakan teknik clustering dengan memberi kesempatan masing-masing mahasiswa menuliskan gagasannya di depan kelas selama 5 menit per masing-masing mahasiswa. Setelah itu mahasiswa yang lain diberi kesempatan untuk memberikan masukannya, sehingga ide awal dalam proses clustering didapat dengan mudah dan menyenang. Kegiatan ini berlangsung 5 x 11 menit $=55$ menit.

\section{Analisis Temuan Siklus 2}

\section{Tindakan}

Siklus 2 ini merupakan perbaikan pembelajaran yang telah dikukan pada siklus 1, maka pada siklus 2 ini semua permasalahan yang telah ditemukan pada siklus 1 diperbaiki. Pada siklus 2 ini pembelajaran menulis teks deskriptif dalam berbahasa Inggris menggunakan teknik clustering dilakukan dengan memberi kesempatan setiap mahasiswa untuk mengembangkan idenya di depan kelas dan dibantu oleh teman-teman lainnya selama 5 menit. Setelah proses ini selesai semua mahasiswa diminta untuk merangkainya menjadi kalimat dan teks utuh mengikuti generic structure dan language features pada teks deskriptif, dan proses ini berlangsung dengan pengawasan dan bimbingan dosen. 


\section{Pengamatan/Observasi}

Hal- hal yang terjadi dalam proses pembelajaran menulis teks deskriptif dalam bahasa Inggris dengan menggunakan teknik clustering pada semester II Prodi TBI pada siklus 2 adalah:

1) Suasana pembelajaran terlihat menyenangkan

2) Mayoritas mahasiswa antusias menulis ide dari topik yang telah dipilihnya sendiri.

3) Mayoritas mahasiswa mampu mengembangkan idenya lebih dari 3 bagian kelompok. Refleksi

Dari hasil pengamatan yang telah dilakukan tersebut dapat disimpulkan bahwa kegiatan pembelajaran pada siklus 2 sudah optimal, karena mayoritas mahasiswa mampu mengembangkan idenya lebih banyak dari siklus 1 dan proses pembelajaran berlangsung menyenangkan. Maka berdasarkan hal ini disimpulkan bahwa pembelajaran menulis teks deskriptif dalam bahasa Inggris menggunakan teknik clustering dengan memberi kesempatan masing-masing mahasiswa menuliskan gagasannya di depan kelas selama 5 menit per masing-masing mahasiswa mampu meningkatkan kemampuan menulis teks deskriptif berbahasa Inggris.

\section{KESIMPULAN}

Proses pembelajaran writing dengan menggunakan teknik clustering dilaksanakan dalam dua siklus. Pada siklus pertama hanya 4 orang mahasiswa yang memenuhi kriteria ketuntasan minimum (KKM), dan ini berarti tidak sampai sebagian dari jumlah mahasiswa yang ada, sehingga perlu dilanjutkan dengan siklus kedua. Pada siklus kedua dilakukan perbaikan dalam proses pembelajaran yaitu dengan memberikan kesempatan 5 menit pada masing-masing mahasiswa untuk menuliskan idenya ke depan dan mahasiswa lainnya memberi ide sesuai dengan topik yang ditulis oleh temannya, dan ide-ide yang terkumpul melalui teknik clustering tersebut disusun menjadi kalimat dan teks deskriptif. Berdasarkan proses pembelajaran writing teks deskriptif meggunakan teknik clustering diperoleh hasil tes yang menunjukkan 81\% mahasiswa memenuhi KKM dan begitu juga hasil observasi menunjukan $81 \%$ mahasiswa aktif dan antusias dalam mengikuti proses pembelajaran. Dari data ini disimpulkan bahwa teknik clustering dapat meningkatkan kemampuan menulis teks deskriptif mahasiswa semester II Prodi TBI TA 2018/2019 pada STAIN Gajah Putih Takengon. 
Kepada para dosen dan guru menulis direkomendasikan untuk menggunakan teknik clustering dalam mengajarkan teks deskrispsi, karena teknik ini merupakan teknik yang sangat menyenangkan dan mampu meningkatkan keaktifan dan antusias mahasiswa dalam mengikuti proses pembelajaran.

\section{DAFTAR PUSTAKA}

Albright, Zoe L and Langan, J. (2013). Exploring writing paragraph and essay. New York: McGraw-Hill Education.

Bailey, S. (2003). Academic writing: A practical guide for students. London and New York: Routledge Falmer Taylor \& Francis Group.

Blanchard, K and Cristine, R. (1994). Ready to write. London: Addition- Wesley Publishing Company.

Brinberg, D., \& Hirschman, E. (1986). Multiple orientations for the conduct of marketing research: An analysis of the academic/practitioner distinction. Journal of Marketing, 50(4), 161-173. doi:10.2307/1251293

Brown, H. (2007). Teaching by principles: An interactive approach to language pedagogy. New York: Longman.

Bryne, D. (1988). Teaching writing skill. London: Longman Group UK limited.

Clark, J., Thorpe, R., Anderson, L., and Gold, J. (2006). It's all action, it's all learning: action learning in SMEs. Journal of European Industrial Training, 30(6), 441-455. doi:10.1108/03090591211232075

Cleant, Brooks and Penn, R. and W. (n.d.). Fundamental of good writing. America: The United States of America.

Collerson, J. (n.d.). Writing for life. NSW: Primary Teaching Association.

Dumais, W. (1988). Writing in English. Jakarta: Departemen Pendidikan dan Kebudayaan.

Finocchiaro, M. (1974). English as second language. New York: Regent Publishing Company.

Gerot, L., \& Wignell, P. (1995). Making sense of functional grammar. NSW: Antipodean Educational Enterprise.

Geyte, E. Van. (2013). Writing: learn to write better academic essays. London: Harper Collins.

Gordon, L. (2009). Writing and good language learners. Multiple Voices Journal, 10(12), 73-81. doi:10.5555/muvo.10.1-2.p563366702323804

Iskandarwassid, S. (2011). Strategi pembelajaran bahasa. Bandung: PT. Remaja Rosda Karya.

Littlejohn, A. (2005). Writing students book 2. Cambridge: Cambridge University Press.

Murray, Rowena and Moore, S. (2006). The handbook of academic writing. England: 
Open University Press.

Murray, N. (2012). Writing essays in English and linguistics. New York: Cambridge University Press.

Nor, Mariam Mohamed \& Ibrahim, A. H. (2009). Writing For ESL teachers. Malaysia: Unipersiti Sultan Idris.

Nunan, D. (1995). Research methods in language learning. TESOL Quarterly. New York: Cambridge University Press.

Nunan, D. (2003). Practical English language teaching. New York: McGraw-Hill.

Oshima, Alice and Hogue, A. (2006). Writing academic writing. America: Pearson Longman.

Oshima, A., \& Hogue, A. (2006). Writing academic English - Level 4 answer key. America: Pearson Longman.

Pardiyono. (2007). Pasti Bisa! Teaching Genre-Based Writing. Jakarta: Andi.

Ruby and Diamond. (2001). Writing and Grammar. New Jersey: Prentice Hall.

Sudijono, A. (2008). Pengantar Statistik Pendidikan. Jakarta: PT Raja Grafindo Persada.

Wyrick, J. (1987). Steps to Writing Well. New York: Rinehart and Winston. Inc. 